\title{
Effects of Local Circulations, Turbulent Internal Boundary Layers, and Elevated Industrial Plumes on Coastal Ozone Pollution in the Downwind Kaohsiung Urban-Industrial Complex
}

\author{
Yee-Lin $\mathrm{Wu}^{1}$, Ching-Ho Lin ${ }^{2,}{ }^{*}$, Chin-Hsing Lai ${ }^{2}$, Hsin-Chih Lai ${ }^{3}$, and Chea-Yuan Young ${ }^{4}$ \\ ${ }^{1}$ Department of Environmental Engineering, National Cheng-Kung University, Tainan 701, Taiwan, ROC \\ ${ }^{2}$ Department of Environmental Engineering and Science, Fooyin University, Kaohsiung 831, Taiwan, ROC \\ ${ }^{3}$ Department of Engineering and Management of Advanced Technology, Chang Jung Christian University, Tainan 711, Taiwan, ROC \\ ${ }^{4}$ Department of Natural Resources, Chinese Culture University, Taipei 111, Taiwan, ROC
}

Received 7 September 2008, accepted 14 April 2009

\begin{abstract}
Linyuan (LY) is a coastal station located downwind of the industrial city of Kaohsiung in southern Taiwan. This station is often affected by severe ozone pollution during sea breeze events. Intensive tethered ozone soundings were performed at this station during a 4-day ozone episode in November, 2005. Back air trajectories were also calculated to track the origins of air masses arriving at the station during the experiment. The investigation revealed complicated ozone profiles in the lower atmosphere (below $1300 \mathrm{~m}$ ) both day and night. At night, industrial plumes forming no-ozone air layers were frequently distributed at $400-800 \mathrm{~m}$. Mixing layers rapidly decreased from $800-1100 \mathrm{~m}$ down to $200-350 \mathrm{~m}$ in the late morning hours when sea breezes and thermal internal boundary layers (TIBLs) developed. Recirculation of polluted inland air masses over the sea, the development of TIBLs, and the late development of sea-breeze events all are likely responsible for severe ozone pollution at the LY station. Elevated industrial plumes or ozone aloft above TIBLs revealed only a minor contribution to ozone pollution via a downward mixing process. Elevated ozone levels (140 - $170 \mathrm{ppb})$ were often trapped within transitional layers of sea-breeze circulations at $600-800 \mathrm{~m}$ and were accompanied by ambient northerly flows parallel to the coastline, suggesting that an ozone pollution core likely formed over the west coast of Taiwan on ozone-episodic days when sea-breeze circulations developed.
\end{abstract}

Key words: Ozone, Tethered sounding, Taiwan, Industrial plume, TIBL, Sea breeze

Citation: Wu, Y. L., C. H. Lin, C. H. Lai, H. C. Lai, and C. Y. Young, 2010: Effects of local circulations, turbulent internal boundary layers, and elevated industrial plumes on coastal ozone pollution in the downwind Kaohsiung urban-industrial complex. Terr. Atmos. Ocean. Sci., 21, 343-357, doi: 10.3319/TAO.2009.04.14.01(A)

\section{INTRODUCTION}

In the lower atmosphere, ozone is produced by photochemical reactions of volatile organic compounds (VOCs) and NOx in the presence of sunlight (National Research Council 1991; Finlayson-Pitts and Pitts 2000). High ozone pollution is usually produced by strong emissions coupled with a stagnant atmosphere on sunny days (Banta et al. 2005). In coastal regions, ozone pollution often occurs during sea-breeze events (Clappier et al. 2000; Boucouvala and Bornstein 2003; Angevine et al. 2004; Ding et al. 2004;

\footnotetext{
* Corresponding author

E-mail: chlin@mail.fy.edu.tw
}

Banta et al. 2005; Kalthoff et al. 2005; Oh et al. 2006; Lin et al. 2007; Talbot et al. 2007).

Weak ambient offshore flows associated with sea-breeze events are known to trigger coastal ozone pollution events (Clappier et al. 2000; Ding et al. 2004; Banta et al. 2005; Oh et al. 2006; Talbot et al. 2007). A sea breeze cannot cause ozone pollution by itself, but can move polluted air masses inland. Polluted sea-breeze air masses typically result from recirculation of polluted air masses originating inland. Seabreeze events that develop under weak ambient offshore flows can increase coastal ozone pollution (Banta et al. 2005); however in this scenario, developing sea breezes must overcome ambient offshore flows and it takes for several hours 
with low wind speeds or even stagnant atmospheric conditions. During this period, ozone precursors can easily accumulate and increase subsequent ozone pollution. The additional pollutants from coastal sources may also contribute to ozone pollution when previously offshore polluted air masses return to coastal regions.

The low mixing depths in coastal regions may also be responsible for coastal ozone pollution. Mixing depth can influence ozone pollution because it limits the extent of vertical mixing of surface-emitted ozone precursors and photochemically produced ozone (Rao et al. 2003). In continental regions, mixing depths on a sunny afternoon typically grows to 1 - 2 kilometers (Stull 1988). However, mixing depths over sea during daytime can be as small as several hundred meters (Hsu and Blanchard 2003). Additionally, in areas near the coast, the mixing depth during a sea-breeze event may still be small. Sea-breeze air masses generally stabilize before moving over land because seawater has a large heat capacity (Simpson 1994; Miller and Keim 2003). When a stable sea-breeze air mass is transported over warm land during the daytime, the bottom portion of the sea-breeze air mass near the ground becomes unstable as heat is gained from the warm land surface. Under such circumstances, an unstable convective mixing layer, the thermal internal boundary layer (TIBL), develops over land (Garratt 1992). Therefore, mixing depths during sea-breeze events are determined by the developed TIBLs. Notably, TIBLs are typically lower than $500 \mathrm{~m}$ when they are $<10 \mathrm{~km}$ from the coastline (Garratt 1992).

Severe ozone pollution has been observed in coastal urban-industrial regions and cities such as the HoustonGalveston Bay region in Texas (Banta et al. 2005), Busan City in Korea (Oh et al. 2006), Marseille City in southern France (Kalthoff et al. 2005), and, as in this study, Kaohsiung City in southern Taiwan. Industrial sources of ozone precursors are known to enhance coastal ozone pollution in these regions and cities. However, industrial sources emit substantial amount of ozone precursors at high altitudes. In this scenario, the effects of industrial sources on coastal ozone pollution are usually related to TIBLs. For example, when the effective plume height of an industrial source exceeds the top of the TIBL in a coastal region, the plume typically remains aloft. Therefore, the industrial source does not contribute to ozone pollution in the coastal region, and vice versa. Surface ozone concentrations even under a condition of downward mixing of ozone precursors from elevated plumes may still be low because the ozone is likely to have been depleted initially in plumes due to NO titration $\mathrm{O}_{3}+\mathrm{NO} \rightarrow \mathrm{NO}_{2}+\mathrm{O}_{2}$ (Finlayson-Pitts and Pitts 2000). The development of a TIBL on coastal air pollution due to emissions from high stacks has been demonstrated (Lyons and Olsson 1973; Portelli 1982; Sawford et al. 1998). These studies concluded that surface pollution typically occurs after the elevated plumes contact TIBLs; however, few ex- perimental field studies have been conducted and most focused on primary pollutants such as sulfur dioxide. Analytical results obtained by studies for primary pollutants such as sulfur dioxide cannot be fully applied to coastal ozone pollution. Thus this study is motivated to further the understanding of coastal ozone pollution in an urban-industrial environment.

This work investigated the origins of severe ozone pollution at the LY coastal station downwind from the urbanindustrial Kaohsiung complex. Intensive tethered ozone soundings were taken at the LY station every 2 - $4 \mathrm{~h}$ during an ozone field study from 31 October to 5 November 2005. Complete diurnal and nocturnal evolutions of vertical distributions of ozone, potential temperature and wind fields were obtained. Back air trajectories were calculated to track the origins of air masses arriving at the station during the experimental period. Based on the experimental observations, a schematic diagram of vertical ozone variations under the influence of land-sea breezes, the development of TIBLs, and the industrial plumes in the coastal environment was presented and discussed.

\section{EXPERIMENTAL SETUP}

\subsection{Site Description}

Figure 1 shows the location of the studied LY station $\left(22.48^{\circ} \mathrm{N}, 120.41^{\circ} \mathrm{E}, 10 \mathrm{~m}\right.$ above sea level) and its surroundings. The LY station is $20 \mathrm{~km}$ southeast of the Kaohsiung city, in southern Taiwan. The coastline is $1500 \mathrm{~m}$ to the west and $600 \mathrm{~m}$ to the south of the station. High ozone levels are commonly monitored at the LY station. The LY station belongs to the Taiwan Air Quality Monitoring Network (Taiwan EPA 2007), in which hourly concentrations of regulated criteria pollutants $\left(\mathrm{O}_{3}, \mathrm{PM}_{10}, \mathrm{SO}_{2}, \mathrm{CO}, \mathrm{NO}_{2}\right)$ and meteorological variables (wind speed, wind direction, temperature, relative humidity) are measured. For about 30 days per year, the daily maximum hourly ozone concentration at the LY air station violates Taiwan's 1-h ozone standard of $120 \mathrm{ppb}$.

Kaohsiung is an densely industrialized city with several industrial parks and county wide (Fig. 1). Linhai (LH), Zenda (ZD), and LY are three representative industrial parks. According to the Taiwan Emission Data System 6.1 (Taiwan EPA 2006), the annual emissions of SOx, NOx and VOCs in southern Taiwan gained from all anthropogenic sources are 79000,207000 , and 214000 tons in 2005 , respectively. The emissions from the three industrial parks and from the Shingda coal-fired power plant (Fig. 1) contributed nearly $100 \%$ of the SOx emissions, $50 \%$ of the NOx and $30 \%$ of the VOCs. The LY Industrial Park is just $500 \mathrm{~m}$ north of the studied station. Moreover, the LH Industrial Park, the biggest industrial park in southern Taiwan, is 8 - 10 km northwest of the studied station. Therefore, sources located in the LY and LH industrial parks have the most potential to be responsible for the observed high pollutants in the studied station. 


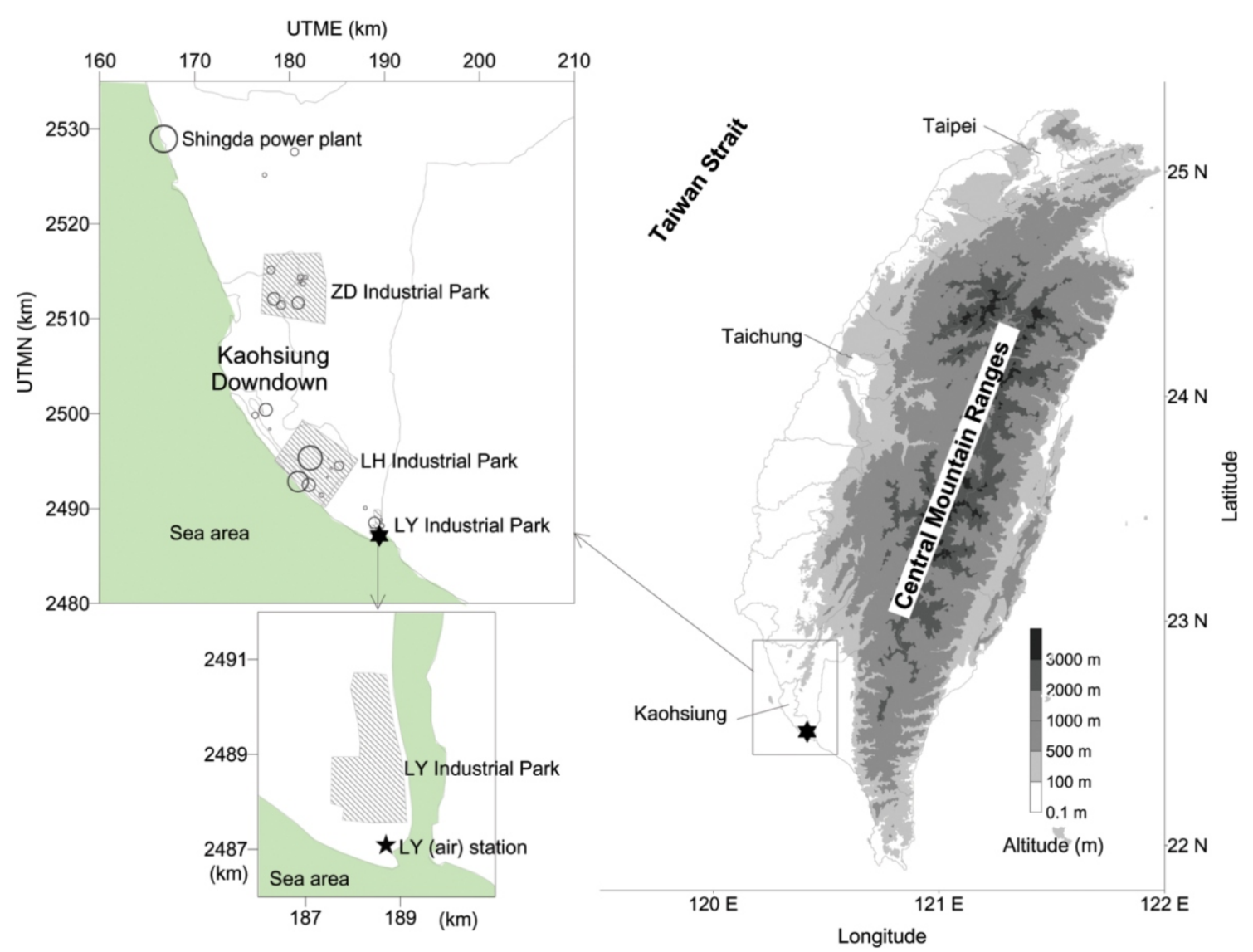

Fig. 1. Location of the Linyuan (LY) measurement site (star) and its surroundings. Major point sources in southern Taiwan are indicated by circles, and the area of each circle is proportional to the annual NOx emission of each corresponding source.

\subsection{Measurements}

A tethered sounding system was used to measure vertical distributions of ozone and meteorological parameters, typically up to $1400-1600 \mathrm{~m}$, every 2 - $4 \mathrm{~h}$ from 31 October to 5 November 2005. This system consisted of a heliumfilled balloon with a diameter of $3 \mathrm{~m}$ attached to an electric winch via a $2 \mathrm{~km}$-long Kevlar line. Ozone was measured by Vaisala TTO111 ozonesondes (Helsinki, Finland) and meteorological parameters (pressure, temperature, relative humidity, wind speed, and wind direction) were measured by Vaisala TTS111 meteorological radiosondes (Helsinki, Finland). Both ozonesonde and meteorological radiosonde were tethered on the tethered line, $25 \mathrm{~m}$ blow the balloon. The ascent and descent of the balloon were controlled using the winch. During the ascent and descent soundings, the vertical variations of the ozone and meteorological parameters were simultaneously acquired. The ozonesonde sensor was a SPC (Science Pump Corporation 1999) model 6A ECC (Electrochemical Concentration Cell). A buffered 1\% KI solution was used in the cathode half-cell and a saturated KI solution was used in the anode half-cell, as suggested by Komhyr (1969) and Komhyr et al. (1995). Before each launch, the meteorological radiosonde was calibrated using the ground check set GC 25 (Helsinki, Finland). Additionally, zero and one-point calibrations of the ECC ozonesonde were performed. The accuracy of the ECC ozonesonde was within $6 \%$ in the lower troposphere (Komhyr et al. 1995). At the start and end of each sounding, the tethersonde was kept at $15 \mathrm{~m}$ above the ground for 3 - $5 \mathrm{~min}$ to compare measurements with those obtained at the LY air station. The LY air station is roughly $100 \mathrm{~m}$ from the sounding site. Figure 2 compares the measurements of hourly $\mathrm{O}_{3}$ concentrations, temperature, wind speed, and wind direction measured at the LY air station and those measured using tethersondes at the start and end of each sounding during November 1 - 4. Generally, the two measuring systems were very consistent (Fig. 2). However, some discrepancies existed, especially nighttime. Some discrepancies were due to the different locations of the two systems and different measurement times. Data from the air station were hourly values and those acquired from soundings were averages for only $3-5 \mathrm{~min}$. Nighttime ozone values measured by ozonesondes were occasionally lower than those measured at the LY air station. These differences may be due to different amounts of ozone dry deposition and different influences by NO titration at the 

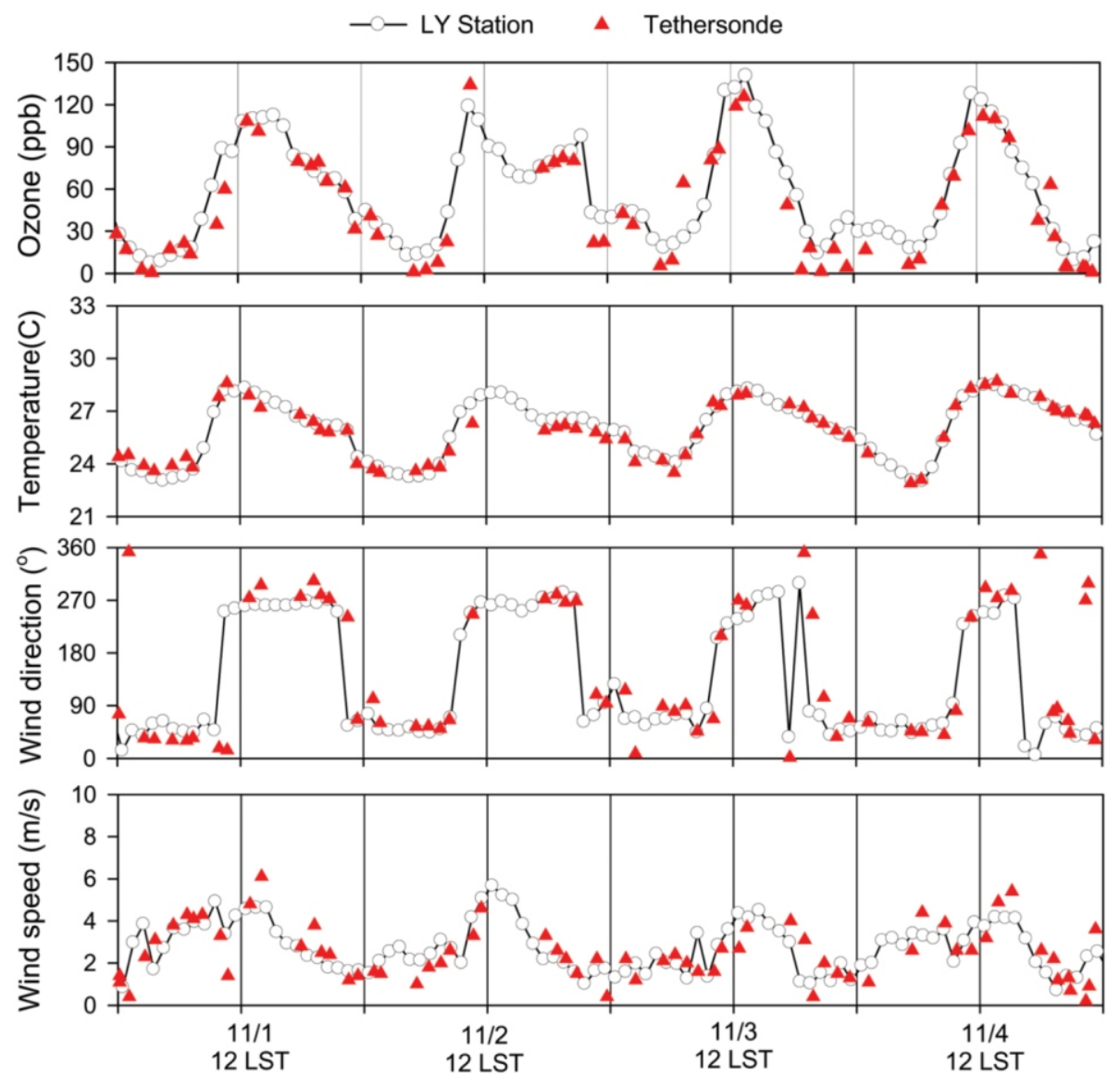

Fig. 2. Comparisons between hourly measurements of ozone $\left(\mathrm{O}_{3}\right)$, temperature $(\mathrm{T})$, wind speed (WS), and wind direction (WD) at the Linyuan (LY) air station and those obtained with tethered ozonesondes during the start and end of each sounding on 1 - 4 November 2005.

two sites. The amounts of ozone dry deposition at the sounding site should be higher than that at the air station because the former is located in an open grassed area and the latter is installed on the concrete roof of a building on the campus of an elementary school. Ozone deposition velocity in the open grassed area should be greater than that on the concrete roof (Wesely and Hicks 2000). Finally, the air station located on the campus should be influenced little by surface NO emissions and, therefore, has a relatively high ozone concentration due to reduced influence by NO titration.

\subsection{Synoptic Weather and Surface Measurements during the Field Study}

During November 1 - 4, synoptic weather in Taiwan was dominated by continental anticyclones centered in the region between the East China Sea and Japan. On November 1 , an anticyclone emanated from mainland China and moved easterly over the East China Sea. On November 2, the anticyclone moved over Japan. Its center moved continuously eastward on November 3. However, the anticyclone produced a separated, minor center near Japan on November 3 (Fig. 3). The situation on November 4 resembled that on
November 3; however, the intensity of the anticyclone system was weaker. The synoptic weather patterns during November 1 - 4 resembled "the back of a high-pressure system" (Cheng 2001; Lin et al. 2004; Peng et al. 2008). This weather pattern was frequently accompanied by ozone episodes in western Taiwan. The synoptic flows were northeasterly to easterly on experimental days, and the flows in western Taiwan were northerly and weakened due to channeling and blocking by the Central Mountain Range (CMR). The influence of the high-pressure system and weak ambient flow in western Taiwan favored the development of sea-breeze events during the experimental period.

Figure 2 shows that daily maximum hourly ozone concentrations were $112,119,140$, and 128 ppb at the LY air station present in the early afternoons of the four days, respectively. Diurnal variations of temperature, wind speed and wind direction suggest that sea breeze (westerly) and land breeze (easterly) dominated each day and night, respectively, during the four experimental days. The onset of the daily sea breeze was at $10-12$ local standard time (LST), and, therefore, the sea breeze was a late event. Notably, the ozone peaks in the early afternoons were accompanied by sea breezes. 


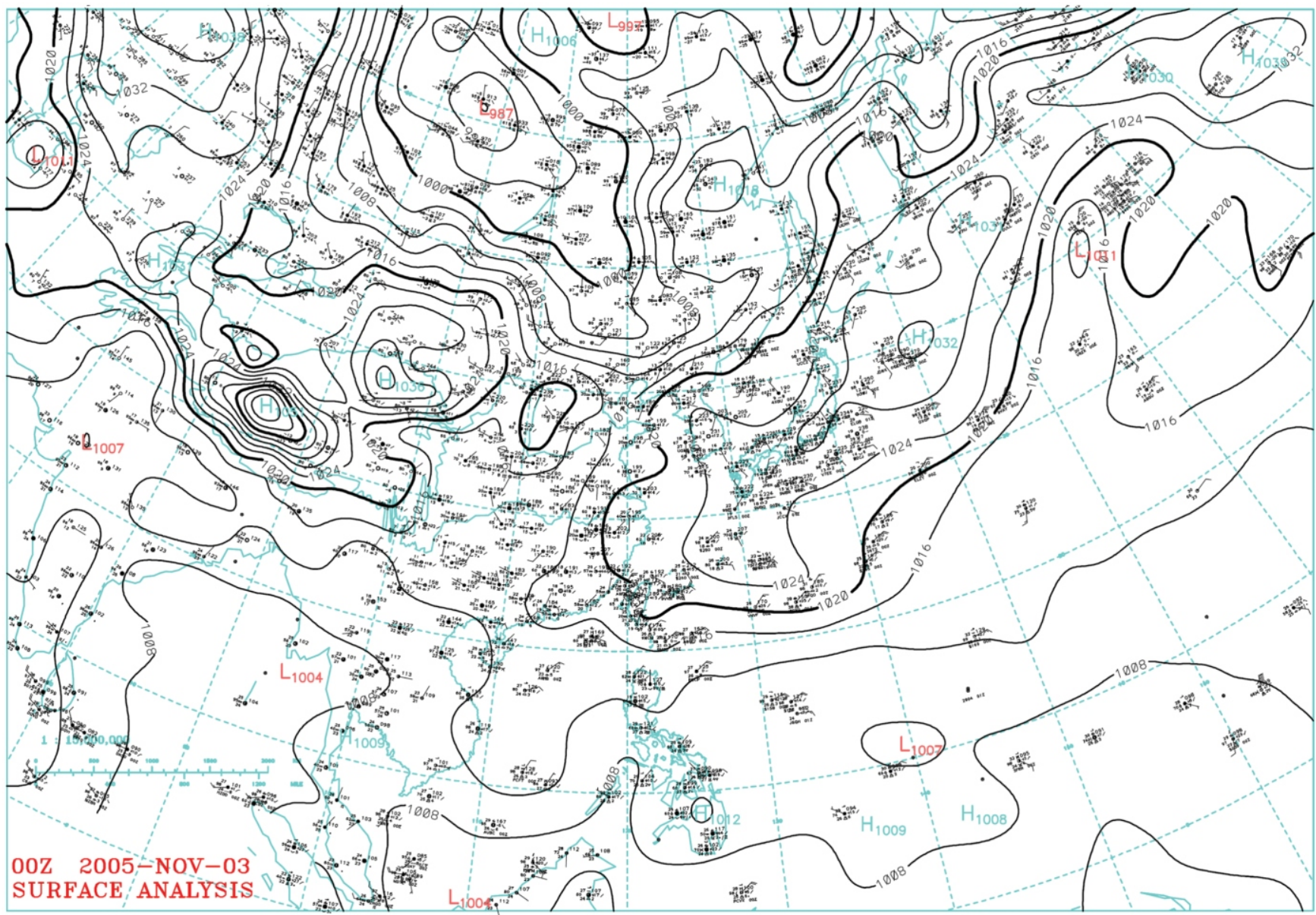

Fig. 3. Synoptic surface weather map for 3 November 2005 (Central Weather Bureau, Taiwan).

\section{RESULTS AND DISCUSSION}

\subsection{Elevated Industrial Plumes Identified by Elevated Low-Ozone Layers at Night}

Figure 4 shows the time-height plots of ozone and wind at the LY sounding site during November 1 - 4. The ozone and wind plots were obtained through linear interpolations of thirty-three tethered soundings. Each tethered sounding included ascendant and descendant measurements, and each was given a sounding number (SN) (Fig. 4). The interpolated variables in the afternoon on November 2 (Fig. 4) are not representative because the data used for the interpolations were limited. Several soundings were canceled in the afternoon due to strong sea breezes. Therefore, the following discussion focuses on the measurements on November 1, 3, and 4 .

At night, air layers with low-ozone concentrations less than $20 \mathrm{ppb}$ were often present at $0-1000 \mathrm{~m}$ (Fig. 4). Figure 5 a shows the detailed ozone profiles associated with elevated low-ozone layers. These ozone profiles (Fig. 5a) clearly reveal that ozone was often completely depleted in some air layers with depths of several hundred meters at 400 - $800 \mathrm{~m}$. These non-ozone air layers were detected repeat- edly on different mornings, and their altitudes were approximately invariant, suggesting that they were caused by regular processes. These non-ozone air layers were most likely related to elevated industrial plumes. An industrial plume is likely quite rich in NO. Therefore, ozone is expected to be mostly depleted from an ambient airflow entrained into an industrial plume by $\mathrm{NO}$ titration $\left(\mathrm{O}_{3}+\mathrm{NO} \rightarrow \mathrm{NO}_{2}+\mathrm{O}_{2}\right)$. Therefore, elevated low-ozone air layers (Fig. 4) and nonozone air layers (Fig. 5a) were mostly likely indicative of elevated industrial plumes. Ozone depletion due to NO titration is rapid (within several min) and significant. Ozone depletion within elevated plumes has been identified in experimental and numerical studies (Senff et al. 1998; Stein et al. 2005; Middleton et al. 2008). During the US 1995 Southern Oxidants Study (Ryerson et al. 1998; Senff et al. 1998), an ozone lidar at a research air plant was utilized to investigate ozone variations in plumes from the Cumberland Power Plant. The generating capacity of the Cumberland Power Plant is $2600 \mathrm{MW}$ comparable to that of the coal-fired power plant $(2700 \mathrm{MW})$ located in the LH Industrial Park in this study (Fig. 1). The measurements of the ozone lidar indicated that ozone depletion due to NO titration occurred 
within the plumes during their initial $3-4 \mathrm{~h}$ of traveling to roughly $50 \mathrm{~km}$ from the power plant. Similar ozone depletion within urban-industrial plumes has also been identified on the Mediterranean coast of the Iberian Peninsula (Stein et al. 2005).

Figures $5 \mathrm{~d}$ - $\mathrm{f}$ show back air trajectories at different altitudes starting from the LY station at 06 LST on November 1,3 , and 4 , respectively. These back air trajectories were calculated based on interpolated wind fields (Fig. 4). The calculations were performed as described in our previous work (Lin and Chang 2002). The trajectories at 400, 600, and $800 \mathrm{~m}$ indicate that the corresponding air masses traveled northerly for at least several hours before arriving at the LY station, a finding consistent with the northerly winds observed at night (Figs. 4, 5c). The back trajectories at 400, 600 , and $800 \mathrm{~m}$ obviously passed over the northern LY Industrial Park, as indicated in small windows (Figs. 5d - f); some trajectories also passed over the LH and/or ZD Industrial Parks. This trajectory analysis, therefore, further demonstrates that the observed non-ozone and low-ozone layers are likely generated by industrial plumes.

Plume rise from the major point sources located in neighboring industrial parks (Fig. 1) were estimated using the formula suggested by Briggs $(1971,1972)$

$\Delta H=2.6\left[\frac{F}{u_{h} S}\right]^{1 / 3}$

$$
F=\frac{g V_{h} d^{2}\left(T_{h}-T_{e}\right)}{4 T_{h}} \text { and } S=g \frac{d \theta}{d z} \frac{1}{T_{e}}
$$

where $\Delta H$ is the plume rise (m); $F$ and $S$ are the buoyancy flux and stability parameter, respectively; $u_{h}$ is the wind speed at the stack height $\left(\mathrm{m} \mathrm{s}^{-1}\right) ; g$ is the acceleration due to gravity; $V_{\mathrm{h}}$ and $d$ are the stack gas exit velocity $\left(\mathrm{m} \mathrm{s}^{-1}\right)$ and the stack diameter (m), respectively; $T_{h}$ and $T_{e}$ are stack gas and ambient air temperature (K), respectively; and $d \theta / d z$ is the change in potential temperature with height $\left(\mathrm{K} \mathrm{m}^{-1}\right)$. Table 1 shows the estimated plume rises, $\Delta H$, and the associated plume heights $(H=\Delta H+h$ where $h$ is the stack height) for typical nighttime stack parameters of large point sources located in the industrial parks and typical atmospheric conditions during the experiment. Apparently, under a light wind $\left(u_{h}=1 \mathrm{~m} \mathrm{~s}^{-1}\right)$ and a nearly statistic neutral condition $\left(d \theta / d z=0.001 \mathrm{~K} \mathrm{~m}^{-1}\right)$ common at night in the experiment (Fig. 5b), the estimated plume heights were in the $407-804 \mathrm{~m}$ range. These estimated plume heights coincide with the altitudes at which most no-ozone air layers were detected (Fig. 5a). Therefore, the elevated low-ozone and no-ozone layers clearly represented industrial plumes. Additionally, ozone depletions can be clearly identified using ozone profiles which also suggest that a tethered ozone sounding is a useful alternative for evaluating plume rises and plume heights.

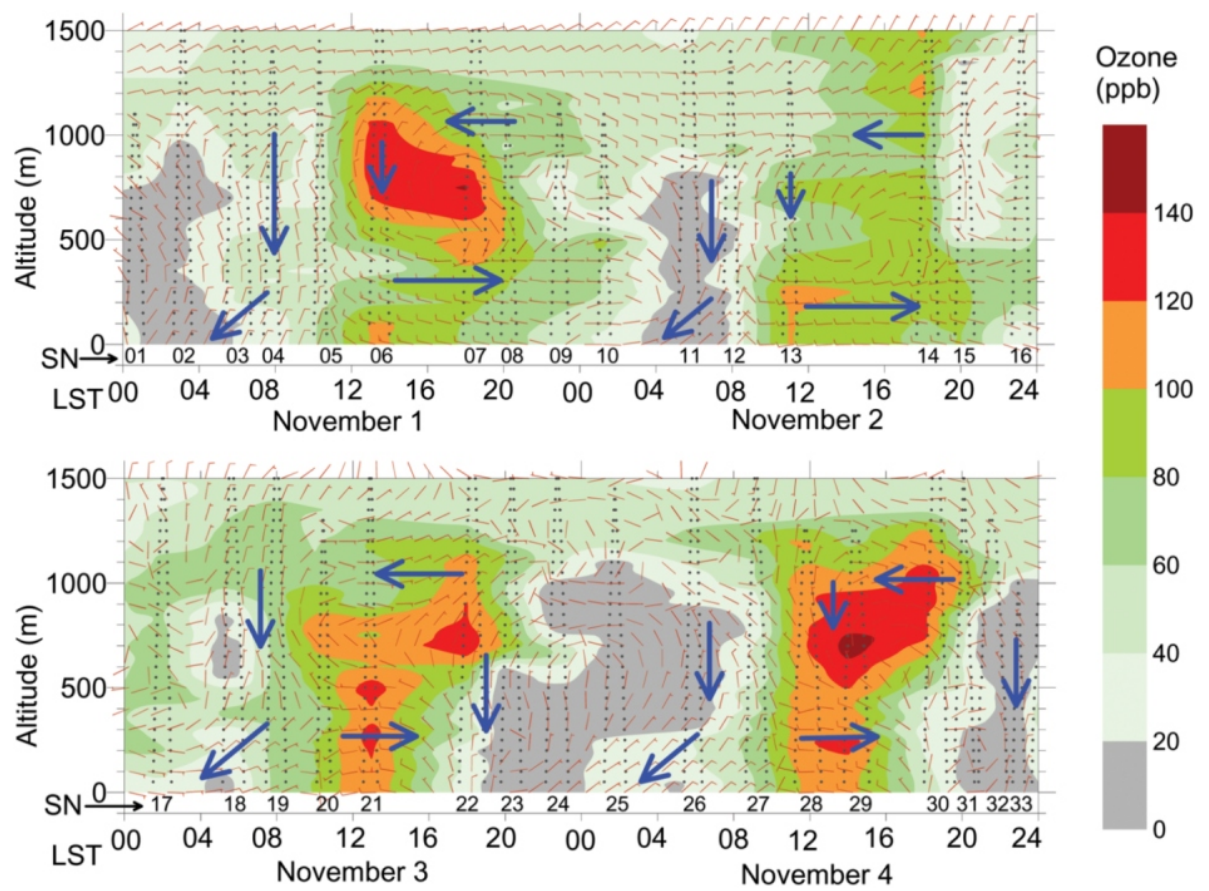

Fig. 4. Time-height plots of ozone in ppb and wind in standard wind bar obtained from the tethered soundings from 1 to 4 November 2005 at the Linyuan (LY) station in southern Taiwan (Fig. 1). The arrows indicate the key flows; each vertical dotted line represents actual time-height relationship of the ozonesonde during each ascending or descending measurement; each sounding was assigned a number (SN) indicated at the bottom of the dotted line. 


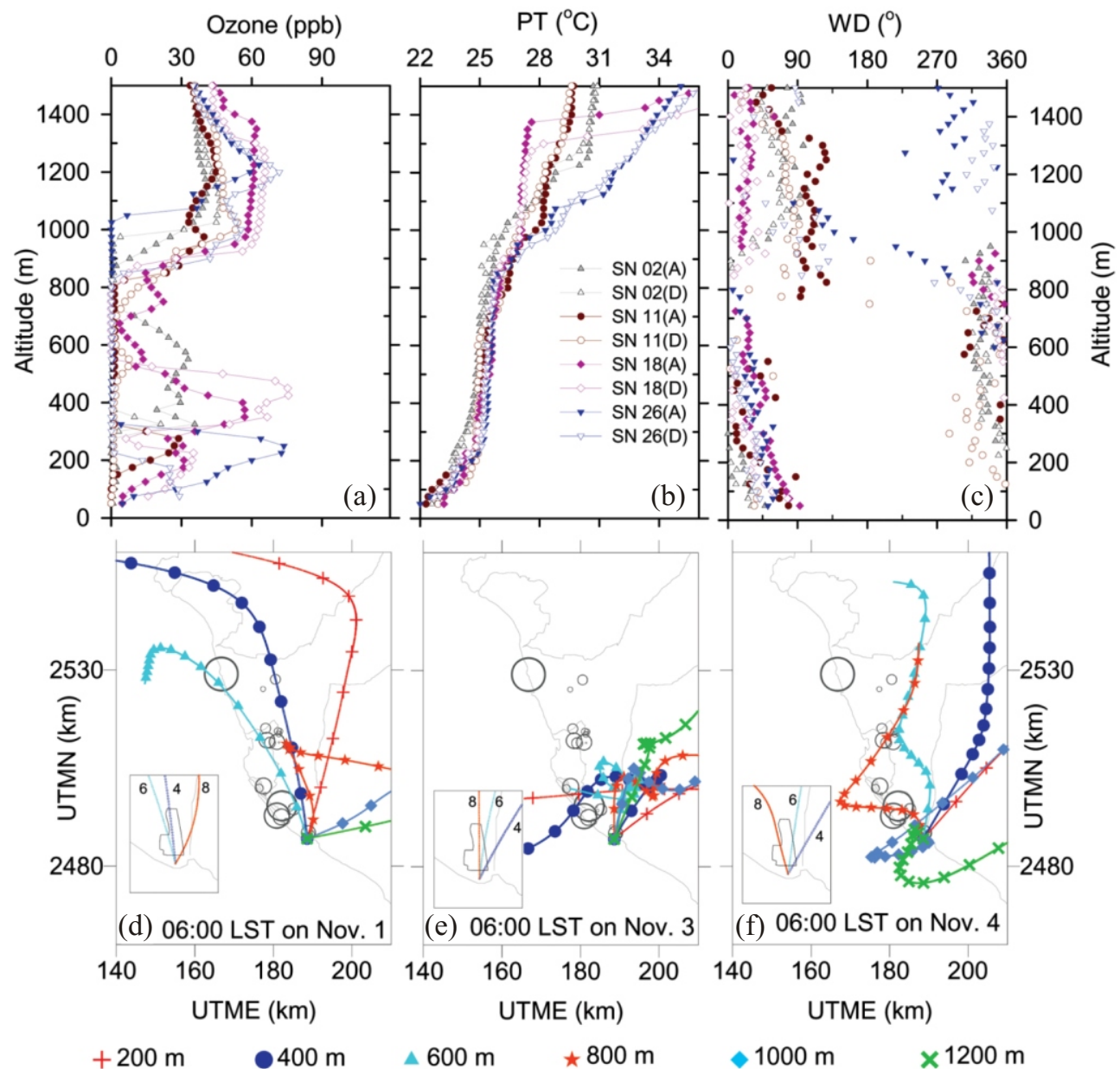

Fig. 5. Vertical profiles of (a) ozone, (b) potential temperature (PT), and (c) wind direction (WD) measured at the LY station during the SN 02 sounding (performed at 0239 - 0338 LST on November 1), SN 11(at 0509 - 0618 on November 2), SN 18 (at 0510 - 0617 LST on November 3 ) and SN 26 (at 0523 - 0622 LST on November 4). The A and D behind the SNs in parentheses indicate ascendant and descendant measurements, respectively. Back air trajectories of 200, 400, 600, 800,1000, and $1200 \mathrm{~m}$ starting at the LY station at 0600 LST on November 1, 3, and 4 are given in channels (d), (e), and (f), respectively. The distance between two adjacent symbols in each trajectory represents one hour; the circles indicate the locations of major point sources in southern Taiwan (Fig. 1). Additionally, small windows in Figs. $5 \mathrm{~d}$ - $\mathrm{f}$ show the trajectories at 400, 600, and 800 $\mathrm{m}$ (numbers 4, 6, and 8 , respectively) near the LY station.

Table 1. Estimated plume rises and plume heights of typical major point sources in southern Taiwan at night.

\begin{tabular}{cccccccccc}
\hline Period & $\mathbf{h}(\mathbf{m})$ & $\mathbf{d}(\mathbf{m})$ & $\mathbf{T}_{\mathbf{h}}(\mathbf{K})$ & $\mathbf{V}_{\mathbf{h}}\left(\mathbf{m ~ s}^{-1}\right)$ & $\mathbf{u}_{\mathbf{h}}\left(\mathbf{m ~ s}^{-1}\right)$ & $\mathbf{T}_{\mathbf{e}}(\mathbf{K})$ & $\boldsymbol{d} \boldsymbol{\theta} / \boldsymbol{d} z\left(\mathbf{K ~ m}^{-1}\right)$ & $\boldsymbol{\Delta} \boldsymbol{H}(\mathbf{m})$ & $\boldsymbol{H}=\Delta \boldsymbol{H}+\boldsymbol{h}(\mathbf{m})$ \\
\hline Night & 80 & 3 & 423 & 10 & 1 & 297 & 0.001 & 327 & 407 \\
Night & 150 & 6 & 423 & 20 & 1 & 297 & 0.001 & 654 & 804 \\
Night & 80 & 3 & 423 & 10 & 2 & 297 & 0.002 & 206 & 286 \\
Night & 150 & 6 & 423 & 20 & 2 & 297 & 0.002 & 412 & 562 \\
Night & 80 & 3 & 423 & 10 & 3 & 297 & 0.003 & 157 & 237 \\
Night & 150 & 6 & 423 & 20 & 3 & 297 & 0.003 & 314 & 464 \\
\hline
\end{tabular}

The $h$ is the stack height; $d$ the stack diameter; $u_{h}$ the wind speed at the stack height; $T_{h}$ the stack gas temperature; $V_{h}$ the stack gas exit velocity; $T_{e}$ ambient air temperature; $d \theta / d z$ the change of potential temperature with height; $\Delta H$ the plume rise; and $H$ the plume height. 


\subsection{Rapid Decreases in Late Morning Mixing Depths Due to Developing TIBLs}

Figure 6 represents time-height plots of potential temperature and tops of daytime mixing layers superimposed onto ozone contours (Fig. 4). The top of the daytime mixing layer in each sounding is also plotted and identified at the altitude at which the first temperature inversion occurred or strong stability above the ground surface existed, as suggested by Stull (1988). Figure 7 presents some examples of the identified daytime mixing layers. Rapid decreases in mixing depths were observed in the late morning hours on November 1, 3, and 4 (Fig. 6). The potential temperature within TIBLs remained almost constant in the afternoons on November 3 and 4 (Fig. 6). This situation should be reasonable since the potential temperature in a TIBL at a study location mainly depends on heat gained by the air mass traveling from the coastline to the study location (Garratt 1992). In the afternoons on November 3 and 4, the sea breezes remained stationary (Fig. 4) and the surface heating rates were stable, explaining why the potential temperature remained almost constant in the afternoons. Increases in potential temperatures mostly above the TIBLs in the upper levels existed during the experimental days from the late morning hours to the afternoons. These increases likely resulted from horizontal transport.

Figure 7a shows an example of rapid development in mixing depth after surface inversion was broken in the morning on November 4. The top of the mixing layer was at $240 \mathrm{~m}$ during the ascendant sounding. Additionally, a nonozone air layer existed at $800-920 \mathrm{~m}$. During the descendant sounding, the top of the mixing depth was at $800 \mathrm{~m}$. However, ozone, potential temperature, water mixing ratio vibrated significantly at $800-1000 \mathrm{~m}$, implying an existence of a transition layer at the altitudes. Northerly winds dominated at $0-1200 \mathrm{~m}$ during this sounding, indicating that the daytime westerly sea breezes did not start by the end of this sounding. Figure $7 \mathrm{~b}$ shows that the mixing depth rapidly decreased near noon time. During the ascending sounding, the top of the mixing layer was identified at $1050 \mathrm{~m}$. However, during the descendant sounding, a small but clear temperature inversion was observed at $300 \mathrm{~m}$, indicating that the top of the mixing layer had decreased from the previous 1050 to $300 \mathrm{~m}$. Moreover, the westerly winds strengthened during this sounding, indicting the development of daytime westerly sea breezes during this sounding period. Apparently, the rapid decrease in mixing depth during this sounding resulted from the development of a TIBL associated with the sea breeze. The evolution of the mixing layer followed collapses due to onset of a sea breeze was observed during the ESCOMPTE experiment over the Marseille area in southern France during 2001 (Delbarre et al. 2005; Puygrenier et al. 2005).

Figures 8 a - c show ozone profiles, potential temperature and wind speed measured in early afternoons of November 1,3 , and 4 . The tops of TIBLs identified from the
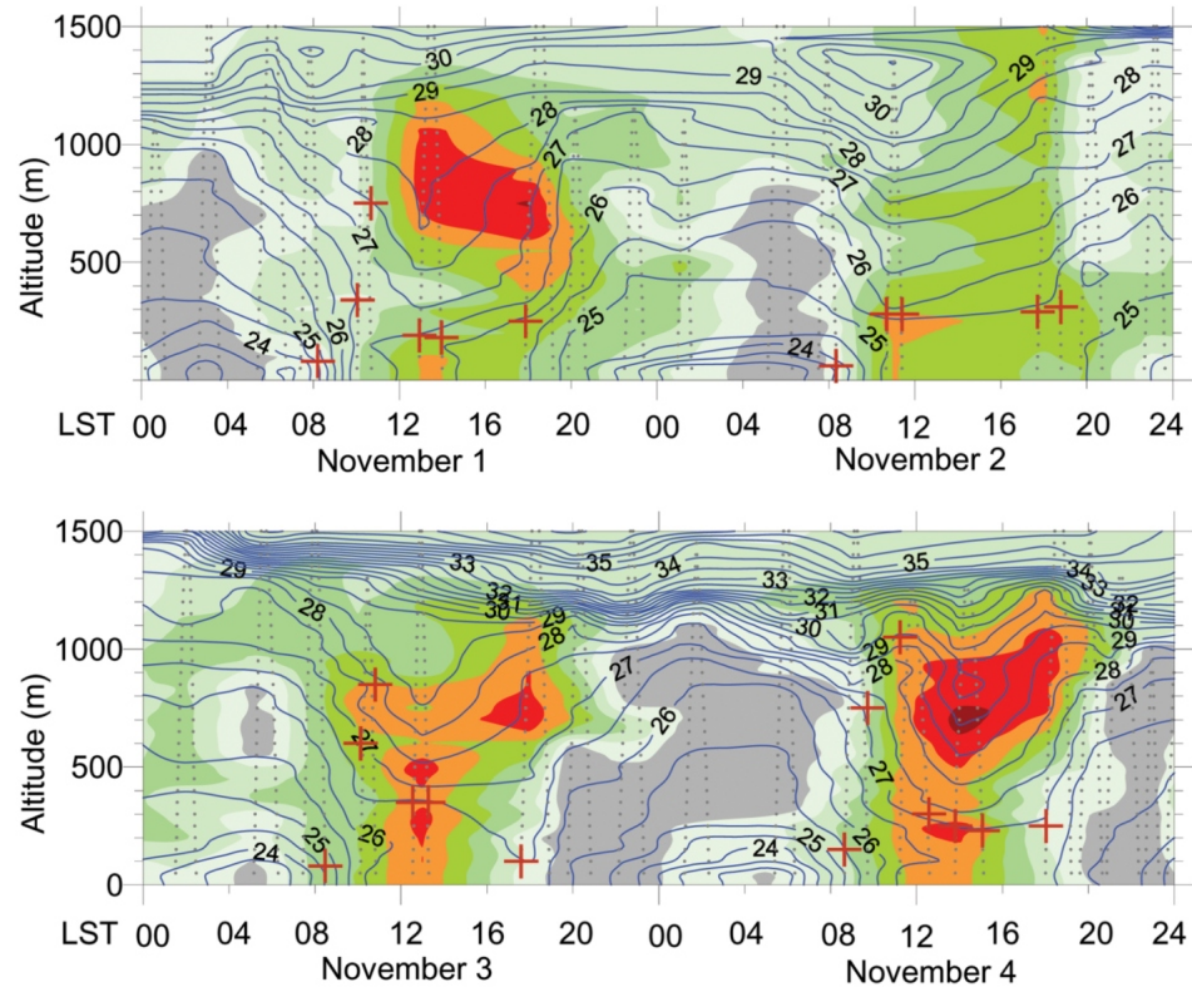

Fig. 6. Same as Fig. 4 with the addition of potential temperature (Celsius) superimposed onto ozone contours. The cross symbols indicate daytime mixing depths identified from potential temperature profiles obtained in each ascending and descending sounding. 
potential temperature profiles in early afternoons in these three days were at 195, 350, and $205 \mathrm{~m}$, respectively. Some low-ozone peaks existed at 300, 400, 550, and $700 \mathrm{~m}$ (Fig. 8a). Back air trajectories at 600 - 800 m (Figs. 8d - f) had previously passed over the northern industrial parks, suggesting that some of the low-ozone peaks were likely related to the nearby industrial plumes. The low-ozone peaks also suggest that ozone was not fully produced in the industrial plumes.
The study LY station is $500 \mathrm{~m}, 10$, and $25 \mathrm{~km}$ from the LY, $\mathrm{LH}$, and ZD industrial parks, respectively. Base on a conservative estimate of a wind velocity of $3 \mathrm{~m} \mathrm{~s}^{-1}$ in the afternoon (Fig. 8c), the times for the plums to travel from the LY, LH, and ZD industrial parks to the sounding site were roughly 5 min, 1, and 2 h, respectively. Ryerson et al. (1998), Senff et al. (1998), and Stein et al. (2005) demonstrated that to gain a net ozone production in typical power plant and urban-in-

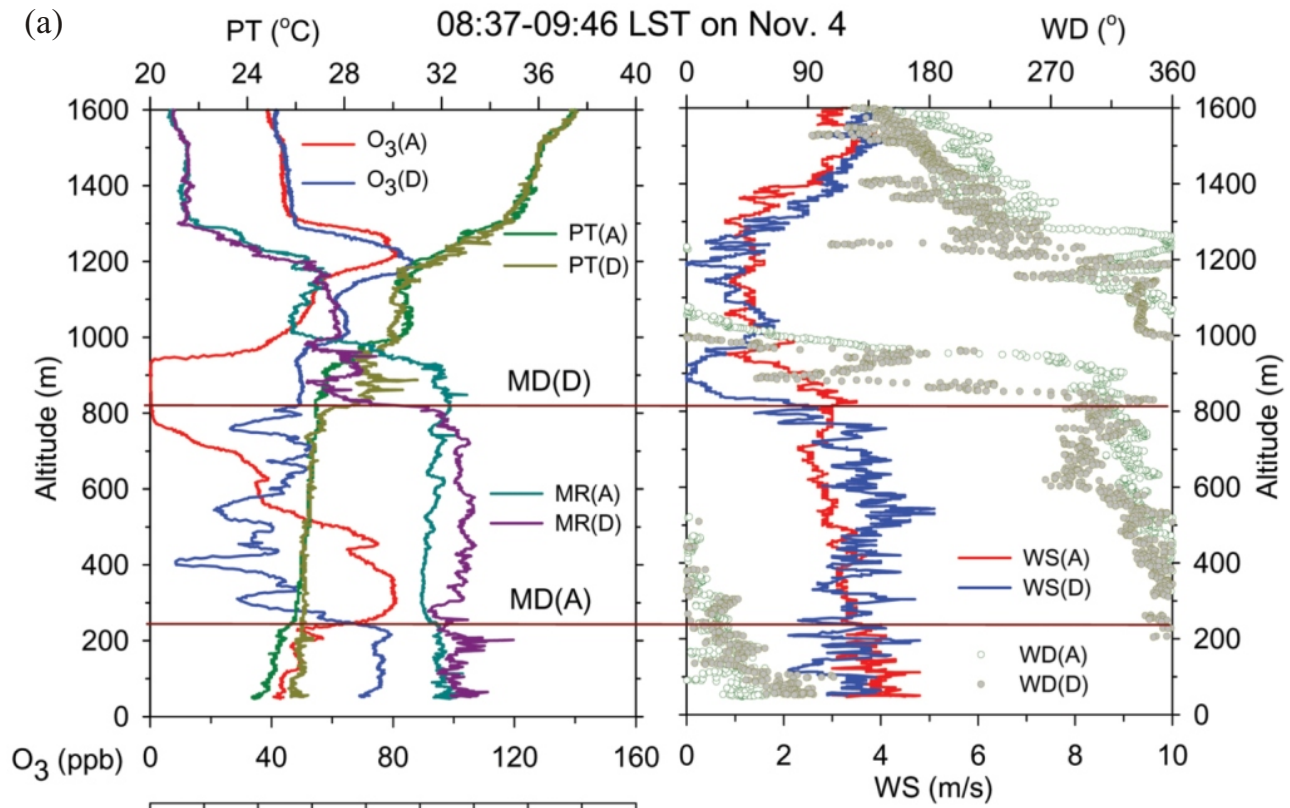

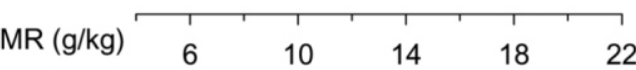

(b)

11:12-12:37 LST on Nov. $4 \quad$ WD $\left({ }^{\circ}\right)$

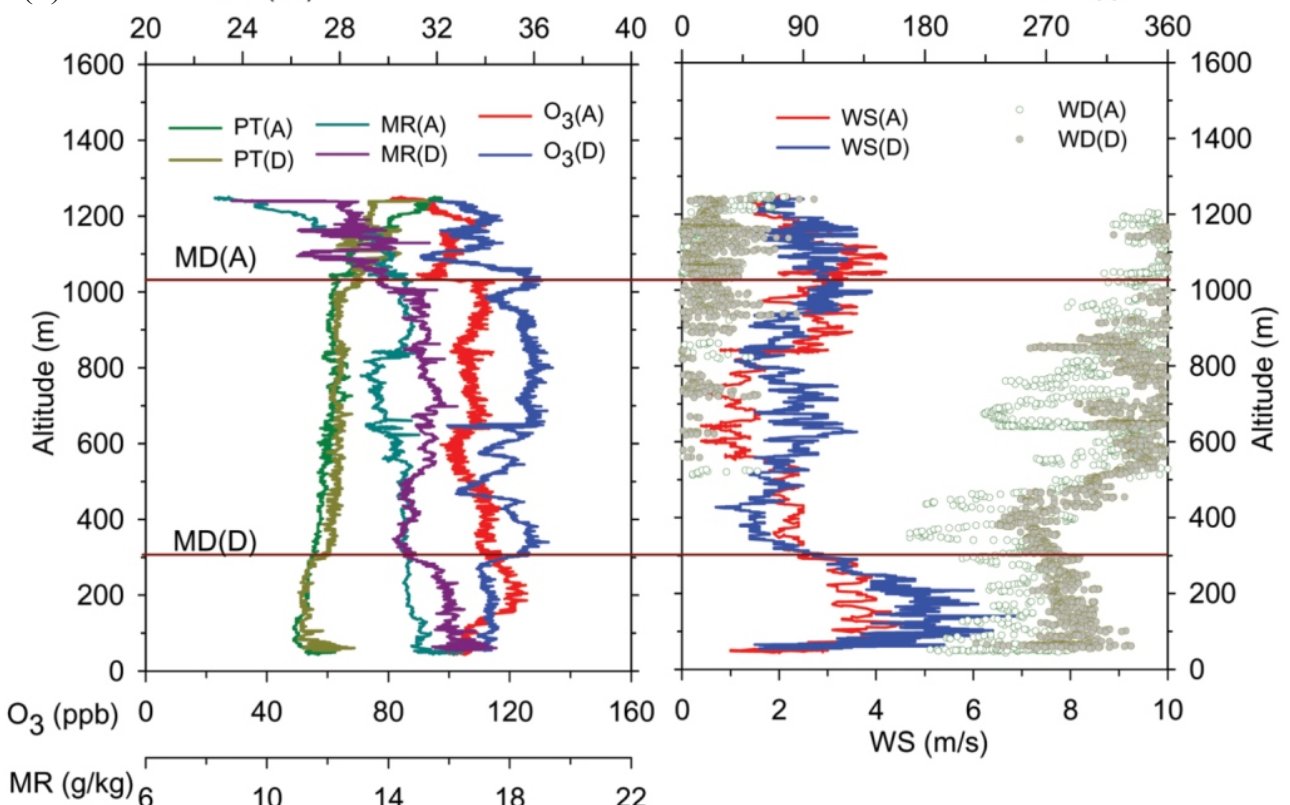

Fig. 7. Vertical profiles of ozone $\left(\mathrm{O}_{3}\right)$, potential temperature (PT), water mixing ratio (MR), wind speed (WS), and wind direction (WD) obtained from tethered soundings at the LY station (a) at 0837 - 0946 LST and (b) 1112 - 1237 LST on November 4. The horizontal lines indicate mixing depths (MDs) identified during ascending (A) or descending (D) measurements. 


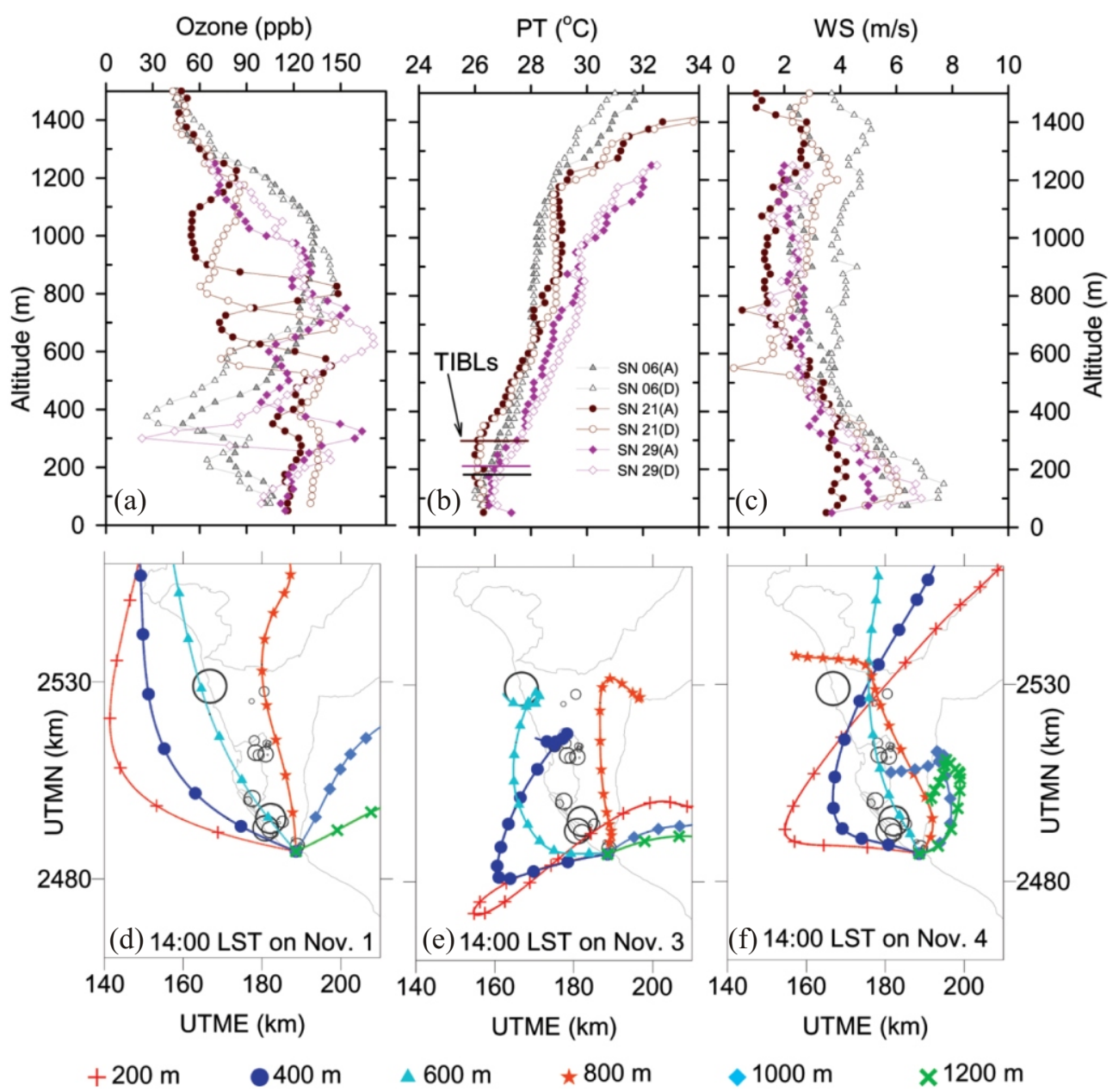

Fig. 8. Same as in Fig. 5, but during the SN 06 sounding (at 1255 - 1400 LST on November 1), SN 21 (at 1232 - 1319 on November 3 ) and SN 29 (at 1345 - 1508 LST on November 4). The TIBL represents turbulent internal boundary layer.

dustrial plumes in the afternoon took 2 - $4 \mathrm{~h}$ and more than 6 $\mathrm{h}$ to fully produce ozone in the plumes. Therefore, the travel times of plumes from the nearby industrial parks to the LY station support that hypothesis that the observed low-ozone peaks (Fig. 8a) resulted from the NO titration in the plumes.

Apparently, the industrial plumes occurred above the TIBLs (Fig. 8b). Consequently, these industrial plumes did not affect the analyzed station via downward mixing process. Very high ozone concentrations of 140 - 170 ppb (Fig. 8a) were detected at $400-800 \mathrm{~m}$. Similarly, these ozone layers were present further above the TIBLs (Fig. 8b). Therefore, they were also unable to influence the study station via downward mixing. Finally, the elevated ozone layers were accompanied by relative low wind speeds (Fig. 8c), implying that they were located in transitional layers of sea-breeze circulations.

\subsection{Causes of Severe Ozone Pollution at the Study Station}

Severe surface ozone pollution of 110 - 140 ppb was present in the early afternoon at the LY station during seabreeze events (Figs. 2, 8a). Previous pathways of these ozone-rich, sea-breeze air masses can be reasonably represented by back trajectories at $200 \mathrm{~m}$ arriving at the LY station at daily 14 LST. The back trajectories at $200 \mathrm{~m}$ on November 1,3 , and 4 (Figs. $8 \mathrm{~d}-\mathrm{f}$ ) showed that the air masses originated inland before moving to the nearby sea daily at $6-8 \mathrm{LST}$ and then remained at sea for the next 6 - 8 hours before finally arriving at the LY station around 14 LST under sea-breeze events. The air masses on November 3 and 4 had previously passed over the Kaohsiung complex before traveling out to sea. These air masses likely acquired abundant ozone precursors as they passed over the Kaohsiung complex at night. During the day, ozone can be produced over sea in the air masses and, then, transport back to LY station associated with sea-breeze events and cause the ozone pollution at the study LY station. Coastal ozone pollution due to recirculation of inland polluted air masses has been identified in Perth, Australia (Hurley and Manins 1995), Busan, Korea (Oh et al. 2006), Houston, USA (Banta et al. 2005), and 
Hong Kong (Ding et al. 2004). Furthermore, as the polluted air masses passed over the Kaohsiung complex, most ozone in the air masses was removed by dry deposition and NO titration. Therefore, ozone concentrations measured in the early afternoons on the experimental days (Figs. 2, 8a) at the LY station were likely produced daily and likely not attributable to abundant background or transported ozone produced on previous days. Moreover, the ozone precursors in the air masses were primarily emitted from near-ground sources rather than elevated point sources such as those with plume heights of $400-800 \mathrm{~m}$ (Fig. 5) because vertical mixing only occurs within the lowest several hundred meters over sea areas (Hsu and Blanchard 2003). Ding et al. (2004) determined that mixing depths over sea were distributed at $200-400 \mathrm{~m}$ based on their numerical simulations for ozone episodic days.

The late development of daytime sea breezes at 10 12 LST likely contributed to the severe ozone pollution at the LY station because the slow development enabled accumulation of ozone in the air masses before they arrived at the LY station. Finally, the development of the TIBL in the studied coastal region during the experiment also likely con- tributed to the ozone pollution at the LY station by continuously and effectively limiting ozone dispersion in the vertical direction within the air masses during their onshore journey between the coastline and the LY station.

Figure 4 shows that elevated ozone layers were present at $600-1200 \mathrm{~m}$ throughout the afternoons on November 1, 3, and 4. Figures $9 \mathrm{a}-\mathrm{c}$ show the detailed measurements for ozone, wind speed and wind direction in the late afternoons of these three days. Comparison of ozone (Fig. 9a) and wind speed (Fig. 9b) profiles reveals that the lower portions (600 $800 \mathrm{~m}$ ) of the ozone layers were associated with relatively low wind speeds. Moreover, the back trajectories at the correspondent altitudes of 600 and $800 \mathrm{~m}$ (Figs. 9d - f) were almost parallel to the coastline. The lower portions of the ozone layers were therefore located in the transitional layers of sea-breeze circulations and traveled northerly along the coastline. However, the upper portions of the ozone layers at $1000-1200 \mathrm{~m}$ (Fig. 9a) were associated with stronger easterly offshore winds (Figs. 9b, c). The back trajectories at the correspondent altitudes of 1000 and $1200 \mathrm{~m}$ (Figs. 9d - f) originated inland in the east, suggesting that the upper portions of the ozone air layers were likely generated by return sea breezes.

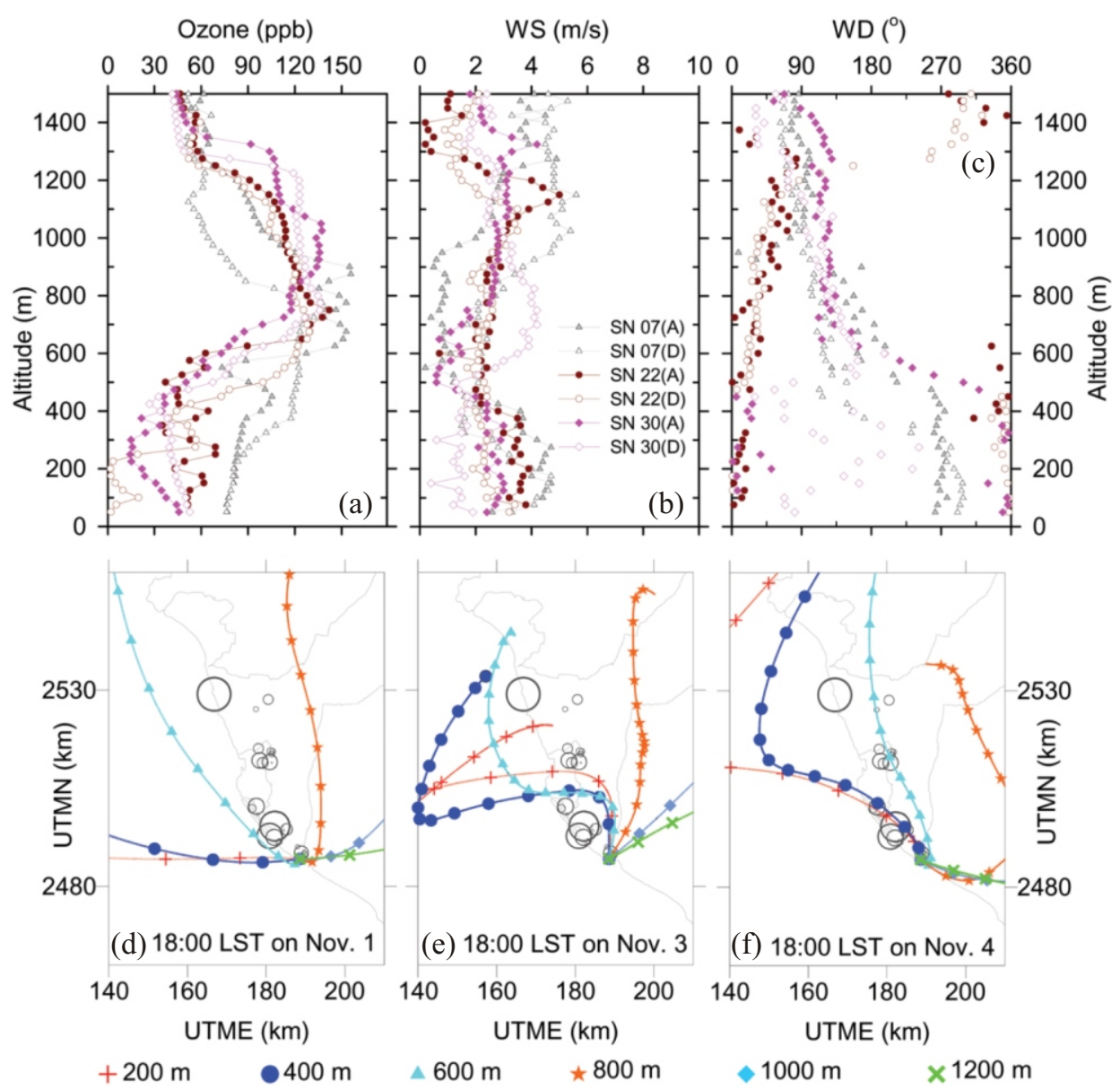

Fig. 9. Same as in Fig. 5, but during the SN 07 sounding (at 1750 - 1911 LST on November 1), SN 22 (at 1734 - 1856 on November 3 ) and SN 30 (at 1757 - 1912 LST on November 4). 


\subsection{Possible Afternoon Formation of an Ozone Pollution Core over Coastal Areas}

Figure 10 shows schematic diagrams that describe possible relationships among vertical ozone variations, land-sea breezes, TIBLs and industrial plumes in the near-coastal study region based on observations by tethered ozonesondes and analysis of back air trajectories. At night, numerous NOx-rich industrial plumes existed over the coastal region, as revealed from elevated non-ozone air layers (Fig. 5a). After sunrise, the stable nocturnal boundary layers broke up (Fig. 6), and distinct pollution layers became mixed by midday (Fig 7a). This process likely caused deep-mixing of NOx and VOCs inland and enhanced subsequent ozone production in all mixing altitudes. Elevated industrial plumes alone were not sufficient to produce ozone because they were rich in NOx but short of VOCs. The VOCs were normally emitted at ground or near-ground levels by mobile sources and some petrochemical facilities in the industrial parks.

In the late morning hours, sea breezes and TIBLs developed (Figs. 6, 7b). The low TIBLs kept industrial plumes and ozone-rich air at upper altitudes (Fig. 8a) and then protected the near coastal area from the downward mixing of the industrial plumes and ozone-rich air. From late morning to early afternoon, the ozone concentrations at lower alti- tudes continuously increased (Fig. 4) because they were dominated by transport of the ozone produced in the daytime over sea in the air masses originated inland (Figs. 8d - f). The minimal vertical mixing of air masses moving toward the studied station and the late development of sea-breezes likely enabled production and accumulation of ozone. The air masses caused serious ozone pollution at the study station. At the same time, both NOx and VOCs were likely rich at upper altitudes due to constant mid-day mixing. Therefore, ozone was continuously produced and accumulated aloft. However, at some altitudes, ozone depletions due to fresh industrial plumes existed above the TIBLs (Fig. 8a). After early afternoon, ozone concentrations in the sea-breeze layers decreased (Fig. 9a) by newly arriving and relatively unpolluted air masses driven by sea breezes (Figs. 9d - f).

In the afternoon, an ozone pollution core likely formed over the coastal region and located in the transitional layer of a sea-breeze circulation because the air in lower altitudes below the transition layer had been replaced with newly arriving and relatively clean sea-breeze air. Similarly, the initial polluted air in upper altitudes above the transition layer had been replaced by clean upper background easterly flows. The ozone pollution core likely formed along the coastline due to northerly ambient flows. The possible formation of the ozone pollution core explained why the highest ozone concentrations were frequently observed in the transitional
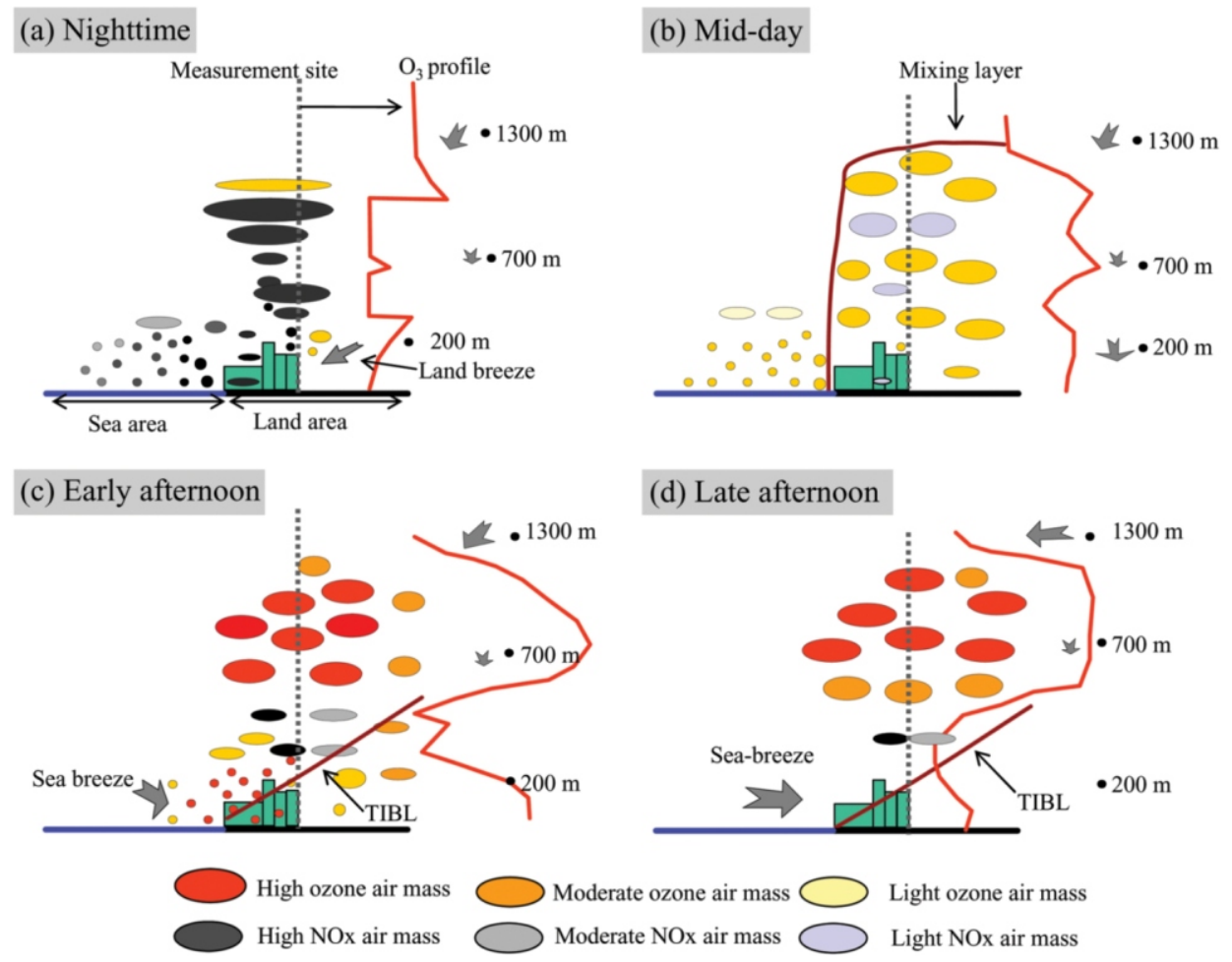

Fig. 10. Schematic diagram of vertical ozone variations under influence of land-sea breezes, development of TIBLs and industrial plumes on high ozone pollution days observed at a coastal station, Linyuan (LY), located downwind of the urban-industrialized Kaohsiung complex, in southern Taiwan, (a) at night, (b) midday, (c) early afternoon, and (d) late afternoon. 
layers of sea-breeze circulations (Fig. 4). The transition layers were located roughly at $600-800 \mathrm{~m}$ where the winds were light and northerly (Figs. 4, 9).

In the late afternoon, some polluted inland air masses were likely transported by return sea breezes over the coastal region and overlaid the transition layer, thereby thickening the elevated ozone layers (Fig. 9a). Ozone trapped within the mesometeorological circulations has been identified in some coastal environments ( $\mathrm{Lu}$ and Turco 1995; McKendry and Lundgren 2000; Millan et al. 2000). These studies identified some possible mechanisms responsible for trapping ozone such as the lofting of pollutants in sea-breeze fronts and injection of convective air masses into inversion layers, advective venting, undercutting of a mixed layer by a advancing sea breeze, injection of pollutants into inversion layers by slope flows, mountain venting and evening stabilization.

\section{SUMMARY}

Ozone soundings were performed during a 4-day ozone episode in November 2005, at the LY station, a coastal site located downwind of Kaohsiung City, an industrial city in southern Taiwan. This investigation identified striking, highly complex vertical distributions of lower-atmosphere ozone over urban-industrial coastal regions. At night and in early morning, numerous elevated low and non-ozone air layers at $400-800 \mathrm{~m}$ were observed frequently. We suggest these low and non-ozone air layers are indicative of industrial plumes emitted from the nearby industrial parks as ozone was completely depleted likely due to titration of considerable NO in the industrial plumes. Tracing the origins of the low-ozone air parcels and analysis of the plumes rising from industrial sources further supported this conclusion. Rapid decreases in mixing depths existed from 800 $1100 \mathrm{~m}$ down to $200-300 \mathrm{~m}$ in the late morning hours due to the development of TIBLs associated with sea-breeze events. The development of TIBLs clearly limited vertical mixing to $<300 \mathrm{~m}$ above the ground for the remainder of the day. These TIBLs can therefore protect the LY station and other near-coastal areas from downward mixing of elevated ozone layers frequently existing at $600-1200 \mathrm{~m}$ in the afternoon and most elevated industrial plumes exceeding $400 \mathrm{~m}$ in height. Back trajectory analysis indicates that the air masses causing considerable ozone pollution at the LY station resulted from recirculation of polluted inland surface air masses. Additionally, elevated ozone layers at $600-800 \mathrm{~m}$ in the afternoon were located in the transition layers of seabreeze circulations and accompanied by northerly winds. These experimental observations suggest that an ozone pollution core likely formed over the west coast of Taiwan on ozone-episodic days when sea-breeze circulations developed.

A preliminary conceptual model (Fig. 10) is presented to describe possible relationships among vertical ozone varia- tions, land-sea breezes, TIBLs, and industrial plumes in the near-coastal study region based on observations by tethered ozonesondes and analysis of back air trajectories. However, the effects of sea breezes, TIBLs and elevated industrial plumes on vertical and diurnal variations of ozone distributions in the study are likely very complex. Further experimental and numerical investigations are warranted to verify and modify the presented conceptual model. For instance, the investigations of other pollutants, such as NO, are important to directly verify the existence of the plumes instead of that of non-ozone air layers in this study. Measurements over the sea are also important to further verify the recirculation of polluted air masses by sea breezes and the character of low mixing depths over the sea. Similarly, measurements for other inland areas are also important for verifying the elevated ozone recirculation of return sea breezes. Finally, detailed simulations of the transport, vertical mixing, photochemical reactions and other processes related to ozone production and removal through photochemical modeling are needed to fully explore the mechanisms responsible for ozone pollution over an urban-industrial coastal region. A sophisticated photochemical model associated with detailed flow simulations would prove to be a highly effective approach in such work.

Acknowledgements The authors would like to thank the National Science Council (Contract No. NSC 94-2211-E242-006) and the Environmental Protection Administration (EPA 94-FA11-03-A202) of the Republic of China, Taiwan, for financially supporting this research.

\section{REFERENCES}

Angevine, W. M., C. J. Senff, A. B. White, E. J. Williams, J. Koermer, S. T. K. Miller, R. Talbot, P. E. Johnston, S. A. McKeen, and T. Downs, 2004: Coastal boundary layer influence on pollutant transport in New England. J. Appl. Meteorol., 43, 1425-1437, doi: 10.1175/JAM2148.1. [Link]

Banta, R. M., C. J. Seniff, J. Nielsen-Gammon, L. S. Darby, T. B. Ryerson, R. J. Alvarez, S. R. Sandberg, E. J. Williams, and M. Trainer, 2005: A bad air day in Houston. Bull. Amer. Meteorol. Soc., 86, 657-669, doi: 10.1175/BAMS86-5-657. [Link]

Boucouvala, D. and R. Bornstein, 2003: Analysis of transport patterns during an SCOS97-NARSTO episode. Atmos. Environ., 37, 73-94, doi: 10.1016/S1352-2310(03)003832. [Link]

Briggs, G. A., 1971: Some recent analyses of plume rise observations. In: Englund, H. M. and W. T. Berry (Eds.), Proceedings of the Second International Clean Air Congress, Academic Press, New York.

Briggs, G. A., 1972: Chimney plumes in neutral and stable surroundings. Atmos. Environ., 6, 507-510, doi: 10.1016/ 0004-6981(72)90120-5. [Link]

Cheng, W. L., 2001: Synoptic weather patterns and their rela- 
tionship to high ozone concentrations in the Taichung Basin. Atmos. Environ., 35, 4971-4994, doi: 10.1016/ S1352-2310(01)00295-3. [Link]

Clappier, A., A. Martilli, P. Grossi, P. Thunis, F. Pasi, B. C. Krueger, B. Calpini, G. Graziani, and H. van den Bergh, 2000: Effect of sea breeze on air pollution in the Greater Athens Area. Part I: Numerical simulations and field observations. J. Appl. Meteorol., 39, 546-562, doi: 10.1175/ 1520-0450(2000)039<0546:EOSBOA>2.0.CO;2. [Link]

Delbarre, H., P. Augustin, F. Said, B. Campistron, B. Benech, F. Lohou, V. Puygrenier, C. Moppert, F. Cousin, P. Freville, and E. Frejafon, 2005: Ground-based remote sensing observation of the complex behaviour of the Marseille boundary layer during ESCOMPTE. Atmos. Res., 74, 403-433, doi: 10.1016/j.atmosres.2004.04.007. [Link]

Ding, A., T. Wang, M. Zhao, T. Wang, and Z. K. Li, 2004: Simulation of sea-land breezes and a discussion of their implications on the transport of air pollution during a multi-day ozone episode in the Pearl River Delta of China. Atmos. Environ., 38, 6737-6750, doi: 10.1016/j.atmosenv. 2004.09.017. [Link]

Finlayson-Pitts, B. J. and J. N. Pitts Jr., 2000: Chemistry of the Upper and Lower Atmosphere: Theory, Experiments, and Applications, Academic, San Diego, California, 969 pp.

Garratt, J. R., 1992: The Atmospheric Boundary Layer, Cambridge Atmospheric and Space Science Series, Cambridge University Press, New York, 336 pp.

Hsu, S. A. and B. W. Blanchard, 2003: Recent advances in air-sea interaction studies applied to overwater air quality modeling: A review. Pure Appl. Geophys., 160, 297-316, doi: 10.1007/s00024-003-8779-2. [Link]

Hurley, P. J. and P. C. Manins, 1995: Meteorological modeling on high-ozone days in Perth, Western-Australia. J. Appl. Meteorol., 34, 1643-1652, doi: 10.1175/1520-0450(1995) 034<1643:MMOHOD>2.0.CO;2. [Link]

Kalthoff, N., C. Kottmeier, J. Thurauf, U. Corsmeier, F. Said, E. Frejafon, and P. E. Perron, 2005: Mesoscale circulation systems and ozone concentrations during ESCOMPTE: A case study from IOP 2b. Atmos. Res., 74, 355-380, doi: 10.1016/j.atmosres.2004.04.006. [Link]

Komhyr, W. D., 1969: Electrochemical concentration cells for gas analysis. Ann. Geophys., 25, 203-210.

Komhyr, W. D., R. A. Barnes, G. B. Brothers, J. A. Lathrop, and D. P. Opperman, 1995: Electrochemical concentration cell ozonesonde performance evaluation during STOIC 1989. J. Geophys. Res., 100, 9231-9244, doi: 10.1029/94JD 02175. [Link]

Lin, C. H. and L. F. W. Chang, 2002: Relative source contribution analysis using an air trajectory statistical approach. $J$. Geophys. Res., 107, 4583-4592, doi: 10.1029/2001JD 001301. [Link]

Lin, C. H., Y. L. Wu, C. H. Lai, P. H. Lin, H. C. Lai, and P. L. Lin, 2004: Experimental investigation of ozone accumulation overnight during a wintertime ozone episode in south Taiwan. Atmos. Environ., 38, 4267-4278, doi: 10.1016/ j.atmosenv.2004.05.003. [Link]

Lin, C. H., C. H. Lai, Y. L. Wu, P. H. Lin, and H. C. Lai, 2007: Impact of sea breeze air masses laden with ozone on inland surface ozone concentrations: A case study of the northern coast of Taiwan. J. Geophys. Res., 112, D14309, doi: 10.1029/2006JD008123. [Link]

Lu, R. and R. P. Turco, 1995: Air pollutant transport in a coastal environment - II. Three-dimensional simulations over Los Angeles basin. Atmos. Environ., 29, 1499-1518, doi: 10.1016/1352-2310(95)00015-Q. [Link]

Lyons, W. A. and L. E. Olsson, 1973: Detailed mesometeorological studies of air pollution dispersion in the Chicago Lake breeze. Mon. Weather Rev., 101, 387-403, doi: 10.1175/1520-0493(1973)101<0387:DMSOAP>2.3.CO; 2. [Link]

McKendry, I. G. and J. Lundgren, 2000: Tropospheric layering of ozone in regions of urbanized complex and/or coastal terrain: A review. Prog. Phys. Geogr., 24, 329-354.

Middleton, D. R., A. R. Jones, A. L. Redington, D. J. Thomson, R. S. Sokhi, L. Luhana, and B. E. A Fisher, 2008: Lagrangian modelling of plume chemistry for secondary pollutants in large industrial plumes. Atmos. Environ., 42, 415-427, doi: 10.1016/j.atmosenv.2007.09.056. [Link]

Millán, M. M., E. Mantilla, R. Salvador, A. Carratala, M. J. Sanz, L. Alonso, G. Gangoiti, and M. Navazo, 2000: Ozone cycles in the Western Mediterranean Basin: interpretation of monitoring data in complex coastal terrain. J. Appl. Meteorol., 39, 487-508, doi: 10.1175/1520-0450(2000) $039<0487$ :OCITWM $>2.0 . C O ; 2$. [Link]

Miller, S. T. K. and B. D. Keim, 2003: Synoptic-scale controls on the sea breeze of the Central New England Coast. Weather Forecast., 18, 236-248, doi: 10.1175/1520-0434 (2003) $018<0236$ :SCOTSB $>2.0 . \mathrm{CO} ; 2$. [Link]

National Research Council, 1991: Rethinking the Ozone Problem in Urban and Regional Air Pollution, National Academy Press, Washington, D. C., 524 pp.

Oh, I. B., Y. K. Kim, H. W. Lee, and C. H. Kim, 2006: An observational and numerical study of the effects of the late sea breeze on ozone distributions in the Busan metropolitan area, Korea. Atmos. Environ., 40, 1284-1298, doi: 10.1016/ j.atmosenv.2005.10.049. [Link]

Peng, Y. P., K. S. Chen, J. C. Lou, S. W. Hwang, W. C. Wang, C. H. Lai, and M. Y. Tsai, 2008: Measurements and mesoscale modeling of autumnal vertical ozone profiles in southern Taiwan. Terr. Atmos. Ocean. Sci., 19, 505-514, doi: 10.3319/TAO.2008.19.5.505(A). [Link]

Portelli, R. V., 1982: The Nanticoke shoreline diffusion experiment, June, 1978 - I: Experimental design and program overview. Atmos. Environ., 16, 413-421, doi: 10.1016/ 0004-6981(82)90151-2. [Link]

Puygrenier, V., F. Lohou, B. Campistron, F. Said, G. Pigeon, B. Benech, and D. Serca, 2005: Investigation on the fine structure of sea-breeze during ESCOMPTE experiment. Atmos. Res., 74, 329-353, doi: 10.1016/j.atmosres.2004. 06.011. [Link] 
Rao, S. T., J. Y. Ku, S. Berman, K. Zhang, and H. Mao, 2003: Summertime characteristics of the atmospheric boundary layer and relationships to ozone levels over the Eastern United States. Pure Appl. Geophys., 160, 21-55, doi: 10.1007/s00024-003-8764-9. [Link]

Ryerson, T. B., M. P. Buhr, G .J. Frost, P. D. Goldan, J. S. Holloway, G. Hubler, B. T. Jobson, W. C. Kuster, S. A. McKeen, D. D. Parrish, J. M. Roberts, D. T. Sueper, M. Trainer, J. Williams, and F. C. Fehsenfeld, 1998: Emissions lifetimes and ozone formation in power plant plumes. J. Geophys. Res., 103, 22569-22583, doi: 10.1029/98JD 01620. [Link]

Sawford, B. L., A. K. Luhar, J. H. Hacker, S. A. Young, I. H. Yoon, J. A. Noonan, J. N. Carras, D. J. Williams, and K. N. Rayner, 1998: The Kwinana coastal fumigation study: I Program overview, experimental design, and selected results. Bound.-Layer Meteor., 89, 359-384, doi: 10.1023/ A:1001758118814. [Link]

Science Pump Corporation, 1999: Operation's Manual Model 6A ECC Ozonesonde, Camden, N. J.

Senff, C. J., R. M. Hardesty, R. J. Alvarez, and S. D. Mayor, 1998: Airborne lidar characterization of power plant plumes during the 1995 Southern Oxidants Study. J. Geophys.
Res., 103, 31173-31189.

Simpson, J. E., 1994: Sea Breeze and Local Winds, Cambridge University Press, UK, 252 pp.

Stein, A. F., E. Mantilla, and M. M. Millán, 2005: Using measured and modeled indicators to assess ozone- $\mathrm{NO}_{\mathrm{x}}-\mathrm{VOC}$ sensitivity in a western Mediterranean coastal environment. Atmos. Environ., 39, 7167-7180, doi: 10.1016/j.atmosenv. 2005.08.026. [Link]

Stull, R. B., 1988: An Introduction to Boundary Layer Meteorology, Kluwer Academic Publishers, London, 666 pp.

Taiwan EPA, 2006: Taiwan Emission Data System 6.1. Taiwan Environment Protection Administration, Taipei, Taiwan.

Taiwan EPA, 2007: Air Quality Annual Report, 2006. Taiwan Environment Protection Administration, Taipei, Taiwan.

Talbot, C., P. Augustin, C. Leroy, V. Willart, H. Delbarre, and G. Khomenko, 2007: Impact of a sea breeze on the boundarylayer dynamics and the atmospheric stratification in a coastal area of the North Sea. Bound.-Layer Meteor., 125, 133-154, doi: 10.1007/s10546-007-9185-6. [Link]

Wesely, M. L. and B. B. Hicks; 2000. A review of the current status of knowledge on dry deposition. Atmos. Environ., 34, 2261-2282, doi: 10.1016/S1352-2310(99)00467-7. [Link] 